Tomasz Fisiak

University of Łódź $z^{*}$

iD https://orcid.org/0000-0002-5514-1287

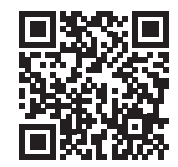

\title{
"Hollywood is no place for idealists": Hollywood as Dystopia in Cinema and Fiction
}

\begin{abstract}
The following article deals with the representation of Hollywood as a dystopian place, for women in particular, where glamour is a utopian façade for both literal and figurative corruption, where the lifespan of an actress is severely limited and the process of discarding "useless" artists is systemically implemented. My main point of reference will be Donald Wolfe's 1970 Savage Intruder, one of the lesser known hag horrors. Moreover, I will allude to other films exploring a similar motif, not to mention Angela Carter's 1977 novel entitled The Passion of New Eve, which also analyzes the falseness of Hollywood and its capacity for dystopia.
\end{abstract}


* Department of Canadian, Intermedial and Postcolonial Studies, Institute of English Studies, University of Łódź

Pomorska 171/173,90-236 Łódź

e-mail: tomasz.fisiak@uni.lodz.pl 
Hollywood could never be reduced to its geographical status only. Since its establishment as a motion picture industry hub, it was more than a "passive receptacle of economic and cultural activity," but "a critical source of successful system performance" (Scott 2015: 1). Frequently referred to as a "dream factory" (Hayward 2002: 185), within a mere ten years since its inception in the 1910s, it managed to produce 90 percent of American films, many of them being exported abroad, thus becoming the most important film industry worldwide (Hayward 2002: 186). Hollywood housed not only film studios, but also their most spectacular "product," i.e. their stars. Numerous actors and actresses could rise to fame almost overnight, lavish mansions were built, fancy parties were organized, scandals followed, and, unsurprisingly, celebrity culture was born, fueled by the audience's demand for gossip and entertainment. And nothing can be as entertaining as somebody's ascent into celebrity heaven or, even more, their subsequent descent into hell. Hence, the term "dream factory" sounds quite ironic; Hollywood produces short-lived glory, treating people as disposable goods that can be easily superseded by new, better models, the older ones being mercilessly discarded.

An equally discomforting term used to describe Hollywood is "Tinseltown," the word emphasizing "the superficially glamorous world [Hollywood] represents" (Oxford Lexico Dictionary). Indeed, behind the façade of fame, career, success and money, lurks failure, doom and oblivion. What seems a perfect utopia is, in fact, a dystopian place. The paper intends to analyze Hollywood as a dystopian territory of systemic destruction of its former heroes/ heroines who are forced to live amongst the ruins and rubble, metaphorically and literally. The main point of reference will be Savage Intruder (1970, ${ }^{1}$ dir. Donald Wolfe), a less known hag horror, as it proves that the dystopian mode can be considered not only a projection of an unpleasant or catastrophic future (Drabble 2000: 312), but also a representation of the present, in particular for women. Actresses, whose lives are broken by Hollywood misogyny and superficiality, constitute an inferior class and are almost literally cut off from the society once their onscreen "expiry date" is over. ${ }^{2}$ Savage Intruder demonstrates that the Hollywood glam is nothing more but a pretense because the city is dirty, dangerous and crammed with threatening psychopaths.

1 Different sources claim other dates, as well: 1968, 1969, 1973, 1975 and 1977. For the sake of consistency, I decided to stick to one, which is 1970 .

2 However, \#MeToo movement proves that young/er actresses also fall victim to Hollywood misogyny. In their case, it is manifested through sexual and physical abuse. Hollywood moguls such as ex-Miramax producer, 
Such a presentation of Hollywood's depravity and unhealthy obsession with female aging became fairly common in the early 1950s, Billy Wilder's 1950 Sunset Boulevard and Joseph L. Mankiewicz's All About Eve (also 1950) being prime examples. However, the emergence of the so-called Grande Dame Guignol at the beginning of the 1960s only reinforced such an image. Grande Dame Guignol, also known as hag horror, hagsploitation movement or psycho-biddy, is defined by Peter Shelley as "a subgenre of the larger film genres of crime, drama, film noir, horror, mystery, and thriller, often appearing with elements of melodrama, comedy, fantasy, and musicals" (2009: 2). Shelley adds that "[o]ften, but not always, the actress playing a grand dame in Grande Dame Guignol had not worked for some time, or this role would be her last starring role. In other cases, it would either lead to a form of typecasting or rejuvenate the actress's career for a time in a fickle industry where the lifespan of an actress is usually five years. Some have criticized the Grande Dame Guignol films for being exploitative of their lead actresses, who had been accustomed to better material in their heydays, and who in these movies were purposely and perversely presented in an unflattering light" (2009: 2-3).

The action of several hag horrors takes place in Hollywood, giving them an ironic twist, as they discuss exploitative and manipulative Hollywood practices, utilizing the very same practices in real life because there was no major difference between the characters and the actresses who played them. Robert Aldrich's What Ever Happened to Baby Jane? (1962), starring Joan Crawford and Bette Davis, two Golden Age icons, was the first one to lay the foundations of this cinematic fad. Crawford and Davis play here Blanche and Jane respectively, two sisters and former actresses, whose bitter rivalry in the horrific Hollywood environment led to their sorrowful demise - the latter turned to alcohol and developed serious mental issues, whereas the former became disabled as a result of a car accident attributed to Jane's booze-induced recklessness. What Ever Happened to Baby Jane? depicts their turbulent relationship, propelled by envy and a ceaseless sense of guilt. They hate each other, at the same time entirely depending on each other, for Jane relies on Blanche's royalties, while crippled Blanche requires Jane's assistance to do the simplest things. The house they live in, once a luxurious mansion, slowly turns into a ruin, adequately reflecting the waste of their inhabitants' lives. Los Angeles/Hollywood might seem a regular city — not for Blanche and Jane, though, for whom it is a strange world keeping them as exotic curiosities from the past, very much reminiscent of species kept in reservations (such as the "savages" in Aldous Huxley's 1932 Brave New World). It is impossible to thrive in a dystopian world of old age, dementia and failed expectations and hopes, so both Blanche and Jane meet a tragic end - Blanche most probably dies as a result of her sister's maltreatment, while Jane, who earlier in the film murdered Elvira, Blanche's nurse, is arrested for manslaughter. The illusion of Hollywood as paradise falls to pieces.

Aldrich's film, its pessimistic tone notwithstanding, turned out to be a major box-office hit and numerous follow-ups were released, most of them relentlessly displaying the abject quality of their female leads. According to Timothy Shary and Nancy McVittie, "[r]einforced by the sheer number of such films made during the 1960s, this representation of elder figures became degrading, transforming older, once sexually desirable female stars into dehumanized objects" (2016: 80; emphasis mine). Some of these productions, similarly to What

Harvey Weinstein, are "in a position of power" and "use this power to demand sexual favours from those of a lower status," actresses becoming their primary targets (Royal 2019: 227). Sadly, "[t]his type of coercive behavior was and continues to be endemic in the entertainment business" (Sammon 2017). 
Ever Happened to Baby Jane?, focused plot-wise on former actresses, once successfully working in Hollywood (or the acting industry in general) before their age, mental state, sudden decline in popularity or other traumatic experiences estranged them from the silver screen for good. The primary examples are Die! Die! My Darling! A.k.a. Fanatic (1965, dir. Silvio Narizzano), What's the Matter with Helen? (1971, dir. Curtis Harrington) and Whoever Slew Auntie Roo? (1972, also directed by Curtis Harrington). However, one of the most peculiar movies to concentrate on a post-success existence of a former starlet and, at the same time, one of the most haunting portrayals of Hollywood as the dystopian wasteland (literally and figuratively) is Donald Wolfe's Savage Intruder (1970), also known under two alternative titles: The Comeback and, more appropriately, Hollywood Horror House, the last one suggestively implying the way in which Hollywood is about to be presented.

The film casts yet another 1930s/40s icon, Miriam Hopkins, as Katharine Packard, a retired actress who has spent her recent years in complete solitude, accompanied only by her faithful secretary Leslie ${ }^{3}$ (played by Gale Sondergaard) ${ }^{4}$ and some servants. Peter Shelley notes that it was Hopkins's only take at Grande Dame Guignol, adding that the film "has garnered fascination because of its obscurity. While easily dismissed as slasher-style exploitation, the film actually has merit. The evocative use of the Hollywood sign, pleasing deployment of music and silence, and good performances all compensate for the sillier aspects of the production" (2009: 116). Allan R. Ellenberger (2018) writes that Savage Intruder "could be filed under the so-bad-it's-good film," emphasizing its inferiority to thematically-related Sunset Boulevard 5 and What Ever Happened to Baby Jane? According to Gregory William Mank, it is "an odd footnote to [Hopkins's] career"; he also observes that the actress plays here "a nightmarish monster of an old movie star" who "is truly disturbing: overacting madly, lasciviously throwing herself at Garfield [David Garfield who plays the character of Vic Valance], drunkenly riding in a Hollywood parade, and giving as off-putting a performance as any «Golden Age» star ever performed” (2015: 100). "Off-putting," however, could be a term easily applied to the way Hollywood is portrayed in this forgotten horror flick.

Savage Intruder opens with a scene of shooting a film interspersed with images of people queuing outside a cinema, champagne being poured, fans cheering for the approaching star. A group of workers prepare a film set. Some of them put large chunks of ice into the mixing machine that produces snow, which somehow serves as a chilling foreshadowing of things to come. Hollywood wastes people's lives and puts them to shreds. Against this significant collage, the director sets a series of photographs presenting the film's female protagonist, Katharine Packard (obviously, these are Hopkins's actual 1930s photos; life and cinematic fiction merge again).

However, the most telling moment is a close-up of the famous Hollywood sign — from a distance, it looks majestic, grand, almost unreal, especially if juxtaposed with sunlit sky and palms. Nevertheless, just a few seconds later, the camera approaches the sign at high speed,

3 Referred to as Lez, which is not a particularly subtle reminder of her strong emotional attachment to Katharine. In a way, the character of Leslie brings to mind Daphne du Maurier's Mrs. Danvers from Rebecca (1938).

4 Sondergaard herself fell victim to the controlling power of Hollywood - her husband, director Herbert Biberman, was accused of being a communist at the peak of the 1950s "red scare" in the US, as a result of which her career came to a halt.

5 Also for Robert Cettl Savage Intruder is an "odd, critically neglected retake on the classic Sunset Boulevard." Cettl adds that it is "[r]arely screened" and the film itself "has no reputation" (2007: 394). 
revealing how torn and dilapidated it is. Metal elements hang from each letter, nails protrude and, most shocking of all, a dismembered female body lies not far from it. The body is as dismembered and shattered as the sign itself. The truth is evident - Hollywood is not going to be presented as the Promised Land, but, rather, as a cesspit of evil of all kinds. Hollywood becomes a perverted reinterpretation of the Holy Rood, with so many lives (actors, directors, crew members, and ordinary workers) sacrificed at the altar of career and fame, where it is very easy to rise from the gutter to the stars and then quickly take the route in the opposite direction. A dystopian Hollywood offers quick success and an equally quick fall.

The sight of a dismembered body immediately sets a sinister, Gothic mood to the film. Soon, yet another discomforting fact will be divulged - there is a homicidal maniac who attacks middle-aged women, kills them and then abandons their mutilated bodies in the vicinity of the Hollywood Hills. Again, selecting such a target is an ironic comment on the utility of women in the film industry. "The star is seen, first and foremost, as an object of desire and is studied in terms of the ways in which spectators identify with, find meaning in and gain a certain fulfilment from his or her image" (Watson 2007: 131). As middle-aged women no longer evoke desire in the volatile cinema-goers, they are pushed aside into oblivion.

The ironic tone is maintained in the next scene depicting a woman in her 50s who listens to the news about the discovery of the aforementioned body. She is at a bar, finishing her drink. The woman looks tired and unhealthy. We can assume that she may be an ex-actress whose career went astray. Once she has finished her drink, she walks home, where she immediately pours herself another glass. However, little does she know that she is the material of a perfect victim, as she was followed home by a mysterious man carrying an ominous-looking bag and that she will be decapitated and torn to pieces in her own bathroom. Just a few minutes into the film, the audience is confronted with two gruesome pictures of bloody violence inflicted on the female body. Hollywood glam is replaced with gore and corruption, order with lawlessness, natural beauty with dirt and horror. The only clean and neatly arranged thing in this chaotic vision is a set of surgical tools with which the psychopath disposes of his female victims.

What also resembles order, at least apparently, is shown in the next scene. A group of tourists take part in a bus excursion around the Hollywood Hills to see the homes of retired actors and actresses. One of them belongs to Katharine Packard. As the guide talks about her mansion, which "once [was] a scene of lavish Hollywood parties," a young girl leaves the vehicle to vomit, thus ruining the utopian effect of coziness, aesthetic pleasure and decorum. At the same moment one more person gets off the tour bus - a young man in a hippie outfit. His bag immediately evokes suspicion as this is where he keeps his box of knives and scalpels. Vic's (the antagonist's) hippie clothing is a sad reminder of how quickly the Summer of Love in 1967 led to the August 1969 murder of Sharon Tate and her friends by members of the Manson Family. The tragedy took place in one of the fancy Beverly Hills villas, comparable with Ms. Packard's house.

Katharine herself appears in a surreal dream sequence that follows Vic's first "savage intrusion" into the house. In her first scene, she is seen preparing herself for a party. Laughter and music can be heard in the background. "Just one more glass of personality," Katharine exclaims as she raises her glass to "dear, loving, loyal friends." In her alcohol-induced frenzy, she keeps blowing kisses, sighs, makes dramatic gestures and accepts tokens of admiration. Soon, the viewers learn that the laughter and joyful noises are nothing more than just a figment of 
a drunk woman's imagination. Dazed and confused, she trips and tumbles down the stairs. Once she falls to the ground, her wig falls off, as well. In this highly exploitative scene, Katharine ends up on the floor, shamed, defeated, in a creased dress, wig lying nearby, i.e. a total antithesis of success usually associated with Hollywood stardom. "Wolfe shows that while the illusion of perfection can be sustained in a long shot, a close-up will expose reality, age, and vulnerability" (Shelley 2009: 116). As a result of the fall, Katharine needs crutches and constant scrutiny. That is when Vic reappears - to hire himself as a nurse to the immobilized star. ${ }^{6}$

Indeed, for Katharine needs company. Friends' visits are few and far between, exposing a bitter truth about the fickleness of the Hollywood industry. At one of the visitors'suggestions, Katharine keeps herself entertained with her old films, similarly to Blanche in What Ever Happened to Baby Jane? However, watching them increases the feeling of loss and longing for the long-gone past. This feeling is strengthened whenever Katharine enters a special room where she keeps her mementos: wax figures wearing her costumes, jewelry, enlarged photographs, and awards. It becomes a utopian space in which she feels homely and where she can slip into a reverie of her former glory. Talking about her old films offers a temporary relief - she admits she has got vivid memories of films she starred in 30 years before, "as if it were yesterday." Therefore, Vic's presence is essential to rejuvenate Katharine, his impudence and vivacity bringing some joy to her life of oblivion, bitterness and despair, even though we know that Vic will have to satisfy his desire for murder ${ }^{7}$ and Katharine (not to mention Leslie) will sooner or later become his victim. To fulfill his evil plan, Vic makes Katharine dependent on him. Firstly, through alcohol he sneaks into the house, very much against Leslie's wishes. Secondly, establishing intimate contacts with his much older charge. The unlikely love affair is doomed to fail from its outset. At the same time, it further confirms how cruel the whole situation is - a woman of a certain age can only depend on a dangerous psychopath to enjoy any sexual gratification.

Nonetheless, before Katharine meets her fatal end, force-fed vodka and murdered by Vic, she throws two parties at her mansion, the first one honoring her much younger lover. An ensemble of embittered actors and directors gathers to criticize modern-day Hollywood, one of the guests aptly observing that "Hollywood is no place for idealists," to which another responds that it is better "for a masochist." Soon after, Vic takes Katharine on a trip around the city, giving his charge a chance to see Hollywood and the rest of Los Angeles for the first time in many years. Katharine refreshes her fond memories of Hollywood when "it was so glamorous"; now, however, it is home to whiskey bars, go-go clubs, strippers, prostitutes, as well as drug and alcohol addicts. The party that Katharine is taken to by Vic further confirms it - a bunch of weirdos and misfits on drugs dance madly in a drug-induced trance, paying tributes to Katharine, who seems to enjoy the hallucinogenic atmosphere. Finally, she feels appreciated and, most of all, noticed. In the act of gratitude, Katharine invites all the party participants to her house. Everybody is either drunk or high. The colorful crowd starts to

6 During a job interview conducted by Leslie, Vic introduces himself as Laurel N. Hardy, it being yet another nod at a more film-savvy audience.

7 Vic himself is a victim of an abusive mother who, as he puts it, was "a lush who slept around, ran off with a pimp, and put me in a foster home." We can assume that such upbringing left scars on his psyche, thus at least partially "rationaliz[ing] his rage against middle-aged women" (Shelley 2009: 118). 
rave among crystal chandeliers and stylish items of furniture. ${ }^{8}$ However, their parade through the spacious rooms at Ms. Packard's mansion bears an uncanny resemblance to the Medieval portrayals of the dance of death, people wearing gaudy outfits and dancing hand in hand with skeletons. Indeed, as one of Katharine's young guests wears a red Santa cape and a skull mask, these iconic images mixing in a trippy dreamscape. Hollywood utopia of glam transforms into a dystopian hell.

Katharine's life also turns into hell. The delusional woman tries to stage her comeback and takes part in a Christmas parade. In what seems to be a drunk vision, but turns out to be Katharine's actual interview, the protagonist is barely able to answer the journalist's questions, only managing to observe that the Hollywood Boulevard has gone downhill and it no longer serves its previous purposes, i.e. glamorous parades and film premieres. According to Katharine, it has changed into a home of "hoodlums and queers." Afterward, Katharine becomes a prisoner in her own house, fully controlled by Vic, who first kills her, then Leslie, then Mildred, the maid, only to be left on his own in the empty mansion, except for Katharine's look-alike dummy.

Overall, such a presentation of Hollywood immediately brings to mind Angela Carter's 1977 novel, The Passion of New Eve. Although its action takes place in a dystopian New York where gangs took control over the city and where the novel's protagonist, Eve/lyn, transitions from a man to a woman, Hollywood plays a vital part. Eve/lyn's new identity and body are modeled on a former Hollywood star, Tristessa de St. Ange (who is later revealed to be a man in drag). Now retired, Tristessa, similarly to Katharine, lives in seclusion in a revolving glass palace, strongly reminiscent of a Gothic castle. Only a mute and deaf butler and a collection of wax effigies of other Hollywood stars observe her slow fading. She sleeps in a fairy-tale-like glass coffin in the so-called Hall of Immortals and feeds mainly on memories of the glamorous past. ${ }^{9}$ Eve/lyn calls her a "tall, pale, attenuated enigma" and "[i]llusion" (Carter 1987: $121,6)$. Certainly, a cult figure and a camp icon, a perfect woman who is no woman at all, Tristessa is a symbolic figure, her very name indicating melancholy and reverie, her gender status resisting obvious categorizations as if to prove that Hollywood is most of all about enigmas and illusions. "With the help of make-up, dress and cinema magic Tristessa managed the act of self-creation. Once again, androgyny, the symbol of perfection and alchemical unity of contradictory elements, appears to be founded on mystification. Tristessa's ontological status remains doubtful since as a woman she is only a celluloid shadow" (Kamionowski 2000: 104). In one of the interviews, Angela Carter claimed that Tristessa was the focal point of her story, not Eve/lyn, because "there is quite a careful and elaborate discussion of femininity as a commodity, of Hollywood producing illusions as tangible commodities" (Haffenden 1984: 36). Katharine is also a product and a commodity, her "false eyelashes, silver nail polish and makeup for the party ... kept for her ordinary day application, ... this constancy show [ing] that she is always artificial and conscious of her appearance" (Shelley 2009: 121). The truth about Hollywood surely causes major discomfort.

8 In his All Movie review, Fred Beldin, who names Savage Intruder "a sick horror update of Sunset Boulevard", notes that the "wild LSD flashbacks" and "convincing bloodshed" make the film "deliciously seedy and sadistic" and worth looking for "its period atmosphere and nasty disposition."

9 In this respect, both Tristessa and Katharine exhibit a close affinity with the Dickensian Miss Havisham from Great Expectations (1861), who also decided never to go beyond a specific phase of her life. 
To sum up, Savage Intruder is a somber reversal of the rags-to-riches story, depicting how glitz and glam fade in the new dangerous reality. Danny Fortune emphasizes the fact that "Old Hollywood is contrasted with New Hollywood through numerous scenes of hippies and assorted rebellious youth thriving in a place that used to stand for glamour and style," praising the film for its interesting analysis of "decadence of late-1960s Hollywood" (2009). The line between decadence and dystopia is very thin. Most probably, the movie producers realized it, as well, for one of the posters advertising Savage Intruder included the following tagline: "She's an aged starlet. He's a twisted psycho. Hooray for Hollywood." Can it get even more ironic?

\section{Bibliography}

Beldin Fred, https://www.allmovie.com/movie/the-savage-intruder-v42988/review [access: 7.07.2020].

Carter Angela (1987), The Passion of New Eve, Virago Press, London.

Cettl Robert (2007), Serial Killer Cinema: An Analytical Filmography with an Introduction, McFarland and Company, Jefferson - North Carolina - London.

Drabble Margaret (2000), The Oxford Companion to English Literature, Oxford UP, Oxford.

Ellenberger Allan R. (2018), Miriam Hopkins: Life and Films of a Hollywood Rebel, The University Press of Kentucky, Lexington.

Fortune Danny (2009), 'The Comeback' a.k.a. 'Savage Intruder': Miriam Hopkins' Decadent Hollywood Mansion Swan Song, https://www.altfg.com/film/the-comeback/ [access: 7.07.2020].

Haffenden John (1984), Magical Mannerist: John Haffenden talks to Angela Carter, "The Literary Review" Nov., 34-38.

Hayward Susan (2002), Cinema Studies: The Key Concepts, Routledge, London - New York.

Kamionowski Jerzy (2000), New Wine in Old Bottles. Angela Carter's Fiction, Wydawnictwo Uniwersytetu w Białymstoku, Białystok.

Mank Gregory William (2015), Women in Horror Films, 1930s, McFarland and Company, Jefferson - North Carolina - London.

Oxford Lexico Dictionary, https://www.lexico.com/definition/Hollywood [access: 7.07.2020]. Royal Kathryn (2019), Journalist Guidelines and Media Reporting in the Wake of \#MeToo [in:] \#MeToo and the Politics of Social Change, eds. Fileborn B., Loney-Howes R., Palgrave Macmillan, London. 
Sammon Paul M. (2017), The Big Ugly [in:] \#MeToo: Essays About How and Why This Happened, What It Means and How to Make Sure it Never Happens Again, ed. Perkins L., Riverdale Avenue Books, Riverdale.

Scott Allen John (2005), On Hollywood: The Place, the Industry, Princeton UP, Princeton Oxford.

Shary Timothy, McVittie Nancy (2016), Fade to Gray: Aging in American Cinema, University of Texas Press, Austin.

Shelley Peter (2009), Grande Dame Guignol Cinema: A History of Hag Horror from «Baby Jane» to «Mother», McFarland and Company, Jefferson - North Carolina - London.

Watson Paul (2007), Stardom and Hollywood Cinema [in:] Introduction to Film Studies, ed. Nelmes J., Routledge, London. 